\title{
THE IMPACT OF THE CONSUMERS' SATISFACTION ON THE ECONOMIC EFFICIENCY OF THE BANK
}

\author{
Andreea Cipriana Muntean ${ }^{1}$
}

\begin{abstract}
In the present conditions, of temperate development of business at a global scale, the organizations want to have clear indications that their investment in the satisfaction of the consumer was worthy and with results. The theoretical base of the operationalization of the relation between satisfaction and the profitability of the organization is quite restricted, still existing challenges for understanding this connection. Of course that both the intensity and the nature of this relation differs from one field to another.
\end{abstract}

Key words: consumer satisfaction, banking services, consumer behavior, repurchase intentions, economic efficiency

JEL code: M 31.

In the present conditions, of temperate development of business at a global scale, the organizations want to have clear indications that their investment in the satisfaction of the consumer was worthy and with results. The theoretical base of the operationalization of the relation between satisfaction and the profitability of the organization is quite restricted, still existing challenges for understanding this connection. Of course that both the intensity and the nature of this relation differs from one field to another.

Although at first sight there is a natural and obvious relation between the satisfaction of the consumer and its loyalty, the relation between the satisfaction of the consumer, loyalty and the profitability of the company was not entirely explained in special literature. The majority of the modeling and / or operationalization tries of this relation were restricted by the unavailability or by the lack of some adequate dates. Temporal data series absence problem concerning the satisfaction of the consumers may be considered an important problem at a micro and macro economical level.

Fornell suggested some benefits which the satisfaction of the consumers has on the company, among which:

- The fidelity of the consumers - in the case of the satisfied consumers there is a much more possibility to buy again the respective product/service. The intense loyalty of the consumers will ensure the company a constant and safe cash-flow, which will be reflected in the company's profits;

- It reduces the price elasticity - the satisfaction of the consumers reduces the price elasticity for current costumers. The satisfied consumers are much more willing to pay for the benefits which they obtain and much more tolerant at the prices increase;

- Transactional reduced costs - a high level of the consumers' satisfaction will determine the future reducing of transactional costs, because it won't be necessary for the company to spend additional in order to attract new clients. The satisfied consumers will buy more frequently and in an increased quantity both the product that satisfied them and other products that the company provides;

- New clients - the costs for attracting new clients are smaller for the companies that provide satisfaction for the effective consumers. These will recommend the respective product/service

\footnotetext{
1 “1 Decembrie 1918” University of Alba Iulia, bologandreea@yahoo.com
} 
to other persons as well (relatives, friends, acquaintances etc.). Also, the media sources will be much more willing to give positive information in order to prospect new buyers;

- Increased reputation - a high level of the consumers' satisfaction will determine an improvement of the company's reputation, what may be an advantage when taking decisions regarding the bringing in of new products, because they increase the consumers' trust and they reduce the risk which he associates to the choice. Also, good reputation is an advantage when it comes to keeping some good relations with the providers, distributors, and the potential business partners.

Even if the reasons which may lead to the judgment according to which the satisfaction of the consumer has as result an increased profitability are many, it isn't always so. At a moment, the company may resort to a diminution of the profits with a view to increase the satisfaction of the consumer. Ensuring the satisfaction of the consumer through high quality, superior design, adequate training of the staff, the variety of the products will lead to costs increasing, which decreases the company's profitability.

In the Figure 1 is presented the connection between quality, value, satisfaction and profitability, as it appears in services field.

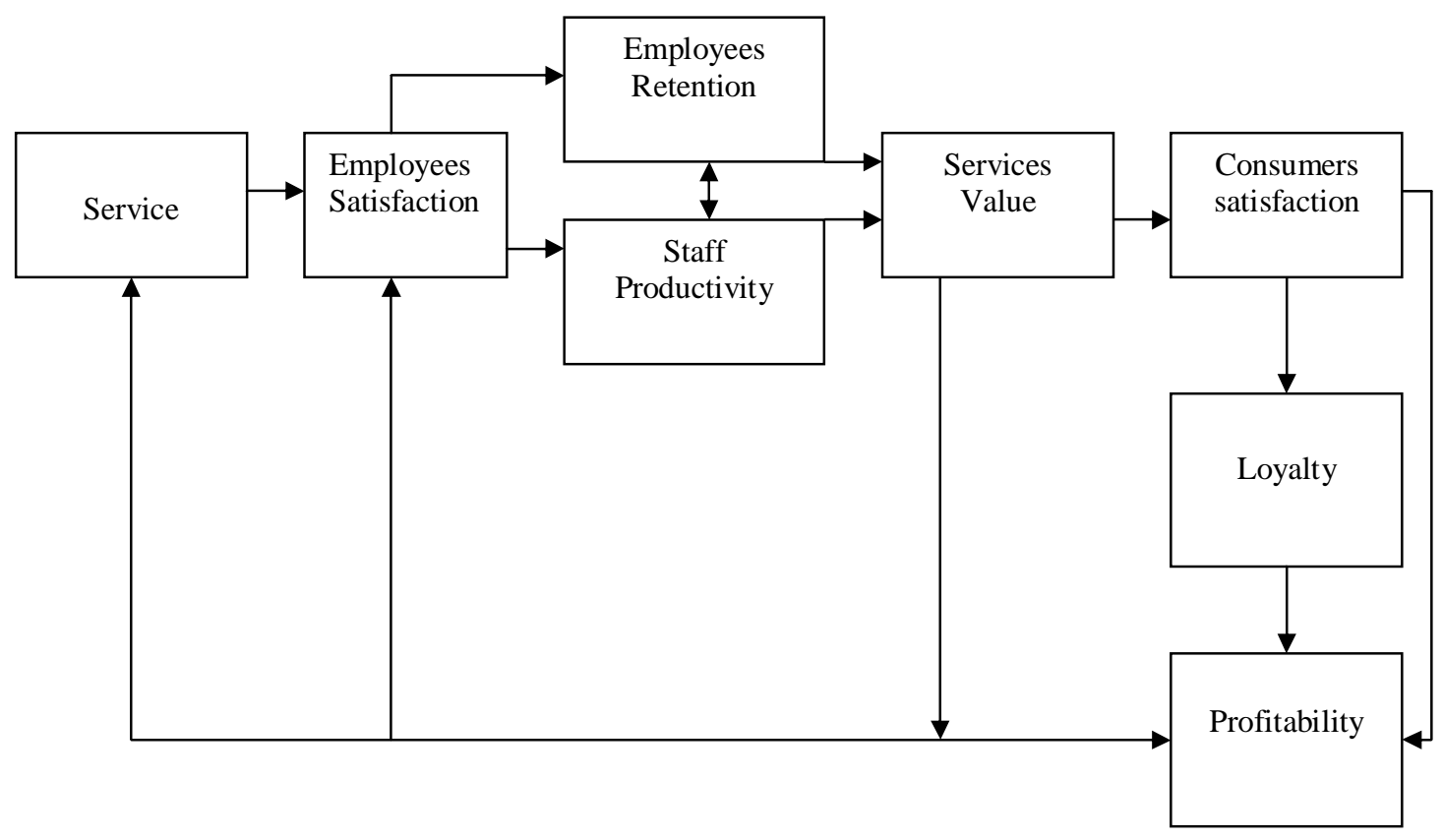

Fig. no. 1 - The Service Chain

Source: Heskett J., Jones T., Loveman G., Sasser E., Schlensinger L., Putting the Service-Chain to Work, Harvard College, 1994

So, it can be appreciated that, by creating a value service, the company satisfies the consumers which will repurchase the product, which will contribute to ensuring the profitability of the respective business.

The connection between satisfaction and profitability may be explained with the help of some inferential methods or some empirical evidence.

The inferential methods used for demonstrating the connection between satisfaction and profitability are named in this way because they place together the satisfaction with information regarding the future intentions of the consumers (such as the probability to buy again the product). 
As a rule, the satisfied consumers manifest a much higher probability to buy again the product or service than those dissatisfied.

From an empirical point of view, the connection between satisfaction and profitability may be demonstrated with the help of two types of methods:

- Longitudinal methodes - they suppose tracing the evolution of the satisfaction and of the profitability at different moments in time. Using these methods is relevant in the case of the organizations which recorded growths in the consumers' satisfaction level from one period to another. The viability of satisfaction - profitability connection analysis highly depends in the way of expressing the profitability, which can be realized in the shape of the profit, of sales level, the rate of turnovers, the market share;

- Transversals methodes - consisted in tracing the satisfaction - profitability connection in the case of many consumers at a given moment in time. Applying this type of method supposes the valuation at an individual level of both satisfaction and performance. Unfortunately, not may organizations dispose of profitability measurements for each client or groups of clients.

At present, a higher attention is given to the way in which the results of researching the consumers' satisfaction may become applicable.

Unfortunately, when it comes to banking industry, there are few organizations, both in the world and in Romania, which dispose of longitudinal profile gathered data, concerning the different levels of clients' satisfaction. The bank CEC S.A is in this situation, which, up to present, does not have at its disposal relevant information concerning the satisfaction level of its clients. This is the main reason for which, when explaining the impact that the consumers' satisfaction has on the economical efficiency of the bank, we resorted to an analysis of the relation between the satisfaction ensemble level and the repurchase intentions. The theoretical frame which stood at the base of this step is reproduced in the Figure 2 and it represents an adjustment on the ACSI model of the consumers' satisfaction.

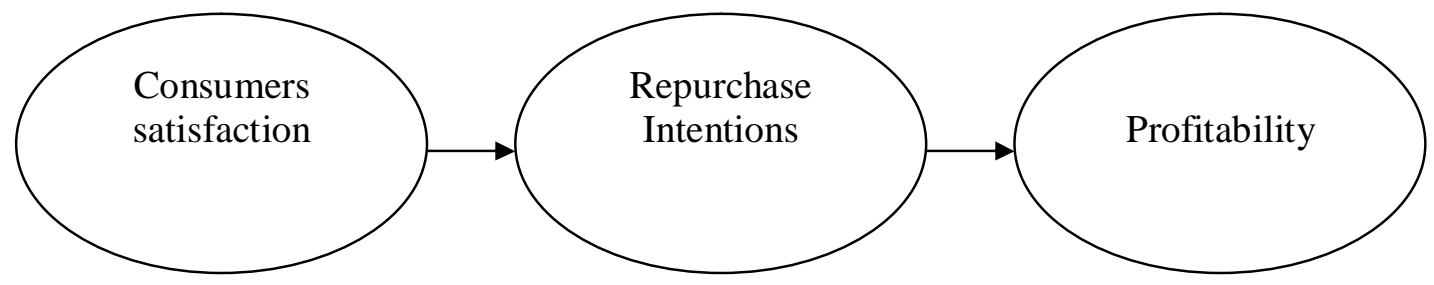

Fig. no. 2 - The satisfaction - repurchase intentions - profitability relation

Source: adjustment on Vavra T., G., Improving Your Measurement of Customer Satisfaction, ASQ Quality Press, Wisconsin, SUA, 1997

For collecting data regarding satisfaction, a selective research among the CEC's costumers from Alba Iulia was organized on a sample of 338 persons, using a questionnaire of 21 questions. There were established 14 main objectives drawn from the purpose of the research, and several secondary objectives, derived from the main ones, based on 5 socio-economic and demographic criteria.

The gathered information concerning the consumers' satisfaction with the banking services of CEC S.A. Alba Iulia demonstrates, as we can also see from the graphic representation below (Figure 3), that the majority of the consumers that manifested their intentions to repurchase the bank's services, over $50 \%$, are satisfied or very satisfied with those services. 


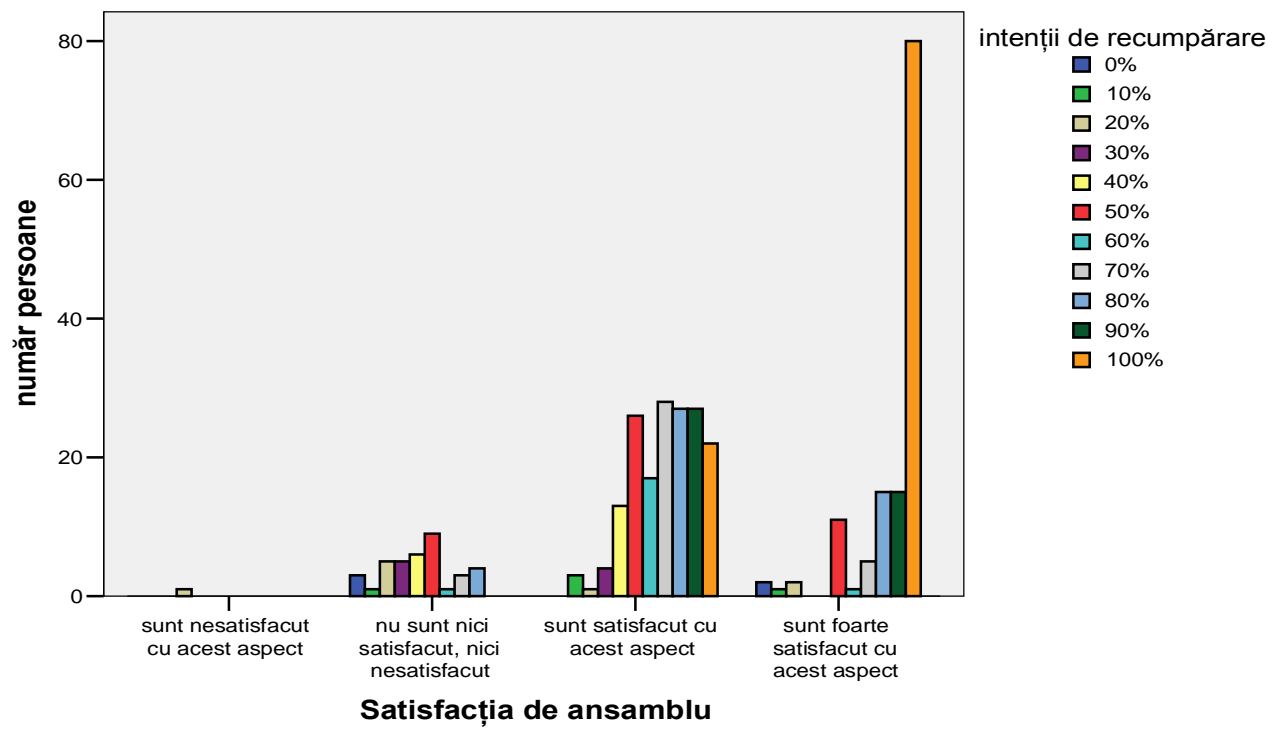

Fig. no. 3 - The intentions of repurchase the bank's services depending on the overall satisfaction

The majority of those that were nor satisfied, nor dissatisfied expressed their repurchase intentions in a $50 \%$ proportion. None of the person dissatisfied manifested his/her intention to return to the bank in proportion higher than $20 \%$.

The first results show that, indeed, the repurchase intentions are influenced by the level of the consumers' overall satisfaction.

Further on, in order to clarify the dependence relation between the two variables, the regression analyze was used. The dependent variable was considered the repurchase intentions and was measured with the help of an interval scale with 11 levels, from $0 \%$ to $100 \%$. The overall satisfaction was the independent variable, and for its measurement was also used an interval scale with 5 levels, from 5 - I'm very satisfied with this aspect, to 1 - I'm very dissatisfied with this aspect.

The obtained results were the following ${ }^{2}$ :

\begin{tabular}{l}
\multicolumn{7}{c|}{ Model Summary } \\
\begin{tabular}{|l|r|r|r|r|}
\hline Model & R & R Square & $\begin{array}{l}\text { Adjusted } \\
\text { R Square }\end{array}$ & $\begin{array}{c}\text { Std. Error of } \\
\text { the Estimate }\end{array}$ \\
\hline 1 & $.544^{\mathrm{a}}$ & .295 & .293 & 21.75029 \\
\hline
\end{tabular}
\end{tabular}

a. Predictors: (Constant), satisfactia de ansamblu

b. Dependent Variable: intentii de recumparare

\footnotetext{
${ }^{2}$ There were reproduced the analyse results exactly in the way in which they appear in the output, generated by SPSS.
} 
ANOVA

\begin{tabular}{|rl|r|r|r|r|r|}
\hline \multicolumn{1}{|c|}{} & \multicolumn{1}{|c|}{$\begin{array}{c}\text { Sum of } \\
\text { Model }\end{array}$} & & & & \\
& & Squares & df & Mean Square & \multicolumn{1}{c|}{ F } & Sig. \\
\hline & Regression & 66643.213 & 1 & 66643.213 & 140.872 & $.000^{\mathrm{a}}$ \\
& Residual & 158953.2 & 336 & 473.075 & & \\
& Total & 225596.4 & 337 & & & \\
\hline
\end{tabular}

a. Predictors: (Constant), satisfactia de ansamblu

b. Dependent Variable: intentii de recumparare

Coefficients ${ }^{\mathrm{a}}$

\begin{tabular}{|c|c|c|c|c|c|c|}
\hline \multirow{2}{*}{\multicolumn{2}{|c|}{ Model }} & \multicolumn{2}{|c|}{$\begin{array}{c}\text { Unstandardized } \\
\text { Coefficients }\end{array}$} & \multirow{2}{*}{$\begin{array}{c}\text { Standardized } \\
\text { Coefficients } \\
\text { Beta }\end{array}$} & \multirow[b]{2}{*}{$t$} & \multirow[b]{2}{*}{ Sig. } \\
\hline & & $\mathrm{B}$ & Std. Error & & & \\
\hline 1 & (Constant) & -17.291 & 7.749 & & -2.231 & .026 \\
\hline & satisfactia de ansamblu & 21.262 & 1.791 & .544 & 11.869 & .000 \\
\hline
\end{tabular}

a. Dependent Variable: intentii de recumparare

The value of the obtained correlation coefficient is $R^{2}=0,295$ and shows that there is a positive and modest correlation between the ensemble satisfaction and repurchase intentions.

The analyze of variance (ANOVA) sustains the statistic significance of the correlation, $p=$ $0,000<0,05$. Consequently, the relation between the two variables may be described with the help of a linear model type:

Where,

$$
\mathrm{Y}=\mathrm{a}+\mathrm{b}^{*} \mathrm{X}
$$

Y - Represents the dependent variable (repurchase intentions);

$\mathrm{X}$ - Represents the independent variable (overall satisfaction);

a - represents the parameter which expresses the estimated value of the intercept;

$\mathrm{b}$ - Represents the estimated value of the parameter which expresses the relation between $\mathrm{X}$ and $\mathrm{Y}$; the plus sign indicates a direct connection, and the minus sign a reverse one.

The values of $a$ and $b$ are found in the third table, within the "Unstandardized Coefficients" heading and are equal with -17.29 and respectively 21,26 ; both values are statisticaly significant ( $\mathrm{p}$ $=0,026<0,05$ and $, \mathrm{p}=0,000<0,05)$.

In other words, the obtained regression equation will have the following form:

The level of repurchase intentions $=-17,29+21,26 \times$ The level of overall satisfaction

The standard error due to estimation is of $\pm 21,75 \%$.

In conclusion, between the intentions of re-buying the bank's services and the ensemble satisfaction level with those, there is a linear and positive relation. Any increasing of the ensemble satisfaction level will lead to an intensification of the re-buying intentions. In time, this can lead to the fidelity of the consumers and, inherently, to the increase of the bank's profits. 


\section{References}

1. Bolton, R.N., Kannan, P.K., 2000. Implications of Loyalty Program Membership and Service Experiences for Customers Retention and Value, Journal of the Academy of Marketing Science, vol. 1.

2. Cătoiu, I., Teodorescu, N., 2004. Comportamentul consumatorului, ediția a II-a, Editura Uranus, Bucureşti.

3. Cătoiu I. (coordonator), 2002. Cercetări de marketing, Editura Uranus, Bucureşti.

4. Cetină, I., Odobescu, E., 2007. Strategii de marketing bancar, Editura Economică, Bucureşti

5. Fornell, S., 1992. A National Customer Satisfaction Barometer: The Swedish Experience, Journal of Marketing, vol. 55.

6. Heskett J., Jones T., Loveman G., Sasser E., Schlensinger L., 1994. Putting the ServiceChain to Work, Harvard College. 